\title{
MEDICINAL PLANTS OF THE BRAZILIAN CERRADO: KNOWING TO PRESERVE
}

\author{
PLANTAS MEDICINAIS DO CERRADO BRASILEIRO: CONHECER PARA \\ PRESERVAR
}

\section{Lucinéia dos SANTOS'; Amanda Martins VIEL ${ }^{2}$; Leandro Fagundes TAROSSO ${ }^{3}$; Luciano da Silva MOMESSO ${ }^{4}$; Dario Abel PALMIERI ${ }^{5}$; Kamille Daleck SPERA ${ }^{6}$}

1. Professora, Doutora, Faculdade de Ciências e Letras, Universidade Estadual Paulista - UNESP - Departamento de Biotecnologia Assis, SP, Brasil. lucineia.santos@ unesp.br; 2. Doutoranda em Biotecnologia, Instituto de Química - Universidade Estadual Paulista UNESP - Araraquara, SP, Brasil; 3. Doutorando em Genética, Universidade de São Paulo - USP - Faculdade de Medicina - Ribeirão Preto, SP, Brasil; 4. Professor, Doutor, Centro Universitário das Faculdades Integradas de Ourinhos - Unifio - Ourinhos, SP, Brasil; 5. Professor, Doutor, Faculdade de Ciências e Letras, Universidade Estadual Paulista - UNESP - Departamento de Biotecnologia - Assis, SP, Brasil; 6. Doutora em Biotecnologia, Instituto de Química - Universidade Estadual Paulista - UNESP - Araraquara, SP, Brasil.

\begin{abstract}
The Cerrado is the second largest biome in Brazil and presents an immeasurable and still underexplored ecological diversity. Despite the exuberance of its endemic species, it is one of the 25 global hotspots, due to a high natural biodiversity wealth along with an expressive environment destruction. In this study, we surveyed the knowledge on medicinal use of Cerrado plants held by individuals living in a predominantly Cerrado region. A semi-structured individual questionnaire for qualitative socio-economic characterization and medicinal use of plants was applied to Public Health Service users of the city of Assis, State of Sao Paulo, Brazil. This study was approved by the Ethics Committee of the Assis Regional Hospital (Protocol 4812010). Out of 149 respondents, 90.6\% reported knowledge and/or use of plants for therapeutic purposes. Among 115 mentioned plant species, only $11.4 \%$ belong to the Cerrado. We also evaluated how matching were the reported uses and the respective published data from scientific studies on the plants' medicinal properties. It was verified that for the few Cerrado plants cited, the respondents described several medicinal applications not scientifically described. More precisely, $60.5 \%$ of all medicinal applications were not found in the scientific literature. Besides that, many of the therapeutic effects described in the literature for the Cerrado species were not cited by the interviewed population. Our results indicate a relative unawareness of people on the medicinal potential of the native species of their residence region. We suggest that strengthening connection between popular and scientific knowledge, along with spreading such knowledge, could contribute for an improved valuation about the Cerrado biome and consecutive preservation of it.
\end{abstract}

KEYWORDS: Popular knowledge. Scientific knowledge. Valuation about the biome.

\section{INTRODUCTION}

Use of medicinal plants dates back to ancient times (DUTRA et al., 2016) and, over time, accumulated empirical evidence produced from popular knowledge has enabled incorporation of phytotherapy into traditional medicine with positive results (SANTOS et al., 2011). With the advent of ethnobotany and ethnopharmacology, many of these plants began to be safely used in the production of herbal medicines for treatment of different diseases, such as infections, tissue inflammation, and pain (EKOR, 2014). It is currently known that several secondary metabolites produced by plants not only protect themselves from herbivory and pathogens, for instance (FÜRSTENBERG-HÄGG; ZAGROBELNY; BAK, 2013; SANCHÉZSANCHÉZ; MORQUECHO-CONTRERAS, 2017), but also have beneficial effects on human health (TAIZ; ZEIGER, 2010). However, in many countries, including those that hold a large biodiversity, the native medicinal flora is still barely studied by scientific methods (RIBEIRO et al., 2014).

The Cerrado is the second largest biome after the Amazon in Brazil. Although the extensive area of $2,036,448 \mathrm{~km}^{2}$ occupied nowadays by this biome (BARBOSA, 2017), much of the Cerrado has already been transformed into pasture, grain crops or devastated for other uses (KLINK; MACHADO, 2005). Currently, only $8,21 \%$ of its total area is fully protected (BARBOSA, 2017). As a result, it is one of the most threatened biomes in the world. According to Mittermeier et al. (2005), the Brazilian Cerrado is one of the 25 global hotspots, areas with concentration of endemic species and exceptional ongoing destruction.

Many communities resident in Cerrado regions are comprised of poor people with restricted access to public health services and often dependent 
of medicinal plants to cure their illnesses (SANTOS; ARAÚJO, 2015). In fact, it is known that the Cerrado carries many plant species with medicinal properties but most of them has not been studied (OLIVEIRA; VIVEIRO, 2012). So, the cultural heritage of the knowledge and use of medicinal plants from this biome argues for the preservation of their species and recovery of the Cerrado areas (DURIGAN et al., 2011).

In this regard, the present study aimed to survey the utilization of medicinal plants by a population of a predominantly Cerrado region and how matching were the reported uses and published data from scientific studies on the plants medicinal properties We further discuss the relationship between the lack of knowledge about therapeutic use of Cerrado plants and the devastation of this biome.

\section{MATERIAL AND METHODS}

This study was conducted in three health units in the city of Assis, Southwest of the State of Sao Paulo (latitude: $22^{\circ} 39^{\prime} 42^{\prime \prime}$ S, longitude: $50^{\circ} 24^{\prime}$ 44 " W, altitude: $546 \mathrm{~m}$ ). This city occupies an area of $460.31 \mathrm{~km}^{2}$ and presents the Cerrado as its predominant natural feature (RIBEIRO-JUNIOR; BERTOLUCI, 2009).

Data were collected for a period of four months by applying a semi-structured individual questionnaire for qualitative socioeconomic character and use of plants for therapeutic purposes to 149 randomly met clients of three public health units. Study subjects declared their voluntariness and anonymous participation by signing Terms of Consent. This study was approved by the Ethics Committee of the Assis Regional Hospital (Protocol 4812010).

Identity of the Cerrado plants cited by the respondents were defined by cross-checking data from the questionnaires and literature reports, especially floristic surveys of areas close to the Assis Ecological Station (ROSSATO; TONIATO; DURIGAN, 2008). We further compared the reported uses of plants with published scientific studies of those same plants in order to check up how they match, classifying the reported uses as either literature-matched (LM) or literaturemismatched (LmM). For the most mentioned use of a given species, a fidelity index representing the percentage of agreement related to the main uses (AMU) was calculated according to the methodology proposed by Friedman et al. (1986) and modified by Amorozo and Gély (1988). The AMU was calculated dividing the number of individuals who mentioned the main use (IMU) for a particular species by the number of individuals who mentioned the same species for any uses (IAU). Thus, the AMU is expressed as a percentage of the final value multiplied by 100 , according to the equation below:

$$
\mathrm{AMU}=\frac{\mathrm{IMU} \times 100}{\mathrm{IAU}}
$$

In order to minimize the error in the AMU calculation due to different therapeutic purposes described for a given plant, derived values were subjected to a correction factor $(\mathrm{CF})$ resulting in a corrected index of agreement on main use (cAMU). This was calculated as follows:

$$
\mathrm{cAMU}=\mathrm{AMU} \times \mathrm{CF}
$$

The correction factor was obtained by dividing the number of individuals who cited a given species in analysis (ISA) by the number of individuals who cited the species with the larger number of therapeutic uses (ISLN).

$$
\mathrm{CF}=\frac{\text { ISA }}{\text { ISLN }}
$$

\section{RESULTS}

Out of the 149 individuals in this study, $76 \%$ (114) were female. Age ranged from 18 to 94 years old and $52 \%$ (77) of them were older than 50 years. The most frequent level of education was the incomplete elementary school (IES), accounting for $39 \%$ (58) of the respondents. In regard to the knowledge and utilization of medicinal plants, $73 \%$ (109) of the subjects declared awareness and use of plants for therapeutic purposes, $17.5 \%$ (26) do not make use of plants despite acquainted to at least one medicinal species, and only $9.5 \%$ (14) do not use and do not have access to any plant. Among the 135 individuals who know and/or use medicinal plants, $23 \%$ (31) were older than 60 and 38\% (51) had lowlevel education (Table 1).

The 135 respondents who cited knowledge and/or use medicinal plants reported 843 uses for them. However, specifically for plants from the Cerrado, out of the 135 respondents, only 42 reported familiarity and/or usage of these plants and 76 medicinal usages were mentioned (Table 2). It is important to clarify that many of the purposes of the medicinal plants cited by the respondents were similar but were accounted for separately. 
Medicinal plants...

SANTOS, L. et al.

Table 1. Age ranges and education level among respondents who know and/or use medicinal plants.

\begin{tabular}{lllllllll}
\hline Age range & NL & IE & CE & IM & CM & IG & CG & TRAR \\
\hline 18 to 19 & - & - & - & - & - & 2 & - & 2 \\
20 to 29 & - & - & 1 & 2 & 8 & 6 & 2 & 19 \\
30 to 39 & - & 7 & 1 & 3 & 10 & 6 & 3 & 30 \\
40 to 49 & - & 8 & 2 & - & 10 & 1 & 3 & 24 \\
50 to 60 & - & 18 & 1 & - & 8 & 1 & 1 & 29 \\
More then 60 & 5 & 18 & 3 & - & 4 & - & 1 & 31 \\
TREL & 5 & 51 & 8 & 5 & 40 & 16 & 10 & 135 \\
\hline
\end{tabular}

TRAR = total respondents by age range; $\mathrm{TREL}=$ total respondents by education level; $\mathrm{NL}=$ non-literate; $\mathrm{IE}=$ incomplete elementary; $\mathrm{CE}=$ complete elementary; $\mathrm{IM}=$ incomplete middle school; $\mathrm{CM}=$ complete middle school; $\mathrm{IG}=$ incomplete graduation and $\mathrm{CG}=$ complete graduation.

Table 2. Level of education and knowledge about medicinal plants among the respondents who know and/or use medicinal plants.

\begin{tabular}{lllllllll}
\hline Knowledge & NL & IE & CE & IM & CM & IG & CG & Total \\
\hline $\begin{array}{l}\text { N of individuals - } \\
\text { Any plant }\end{array}$ & 5 & 51 & 8 & 5 & 40 & 16 & 10 & 135 \\
$\begin{array}{l}\text { N of citation - } \\
\begin{array}{l}\text { Any plant } \\
\text { N of individuals - }\end{array}\end{array}$ & 51 & 282 & 50 & 29 & 255 & 103 & 66 & 843 \\
$\begin{array}{l}\text { Cerrado plant } \\
\text { N of citation - }\end{array}$ & 1 & 18 & 2 & 2 & 12 & 3 & 4 & 42 \\
Cerrado plant & 33 & 3 & 5 & 23 & 5 & 6 & 76 \\
\hline
\end{tabular}

$\mathrm{N}=$ number; $\mathrm{NL}=$ non-literate; $\mathrm{IE}=$ incomplete elementary; $\mathrm{CE}=$ complete elementary; $\mathrm{IM}=$ incomplete middle school; $\mathrm{CM}=$ complete middle school; $\mathrm{IG}=$ incomplete graduation and $\mathrm{CG}=$ complete graduation.

Hundred-fifteen medicinal species were cited by their popular names by the respondents. Out of them, $11.4 \%$ (13) were Cerrado plants. For these 13 species, there were 76 use citations, composing a set of 13 different therapeutic uses: bronchitis and asthma, burn, cold and flu, diabetes, diverticulitis, headache, menstrual cramps, reduce cholesterol, soothing, stomach pain, sprain, and hematoma, weight loss and wound healing (Table 3 ). Only 30 of the 76 use citations for the plants were found in the literature, $39.5 \%$ of the total.

Table 3. Cited Cerrado species, according to their family, popular names and referred therapeutic uses.

\begin{tabular}{|c|c|c|c|c|}
\hline Family & Cerrado species & Popular Name & $\mathbf{N C}$ & RU (LM or LmM) \\
\hline \multirow{3}{*}{ Asteraceae } & $\begin{array}{l}\text { Achyrocline } \quad \text { satureoides } \\
\text { (Lam.) DC. }\end{array}$ & Macela-do-campo & 4 & $\begin{array}{l}\text { Headache }(2 \text { LmM }) \text {, stomach } \\
\text { pain }(1 \mathrm{LM}) \text {, menstrual cramps } \\
(1 \mathrm{LM})\end{array}$ \\
\hline & $\begin{array}{l}\text { Baccharis trimera (Less.) } \\
\text { DC. }\end{array}$ & Carqueja & 38 & 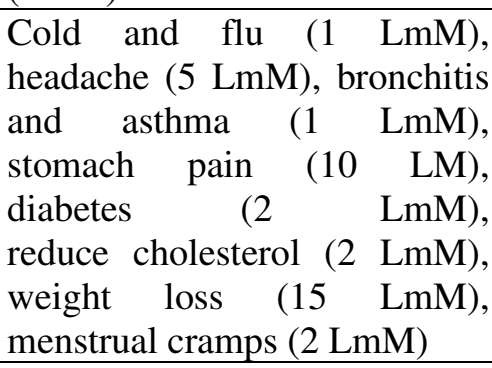 \\
\hline & Hypericum perforatum $\mathrm{L}$. & Erva-de-São-João & 5 & $\begin{array}{l}\text { Soothing }(3 \mathrm{LmM}) \text {, menstrual } \\
\text { cramps }(2 \mathrm{LmM})\end{array}$ \\
\hline \multirow{2}{*}{ Mimosaceae } & Anadenanthera colubrina & Angico do Cerrado & 2 & $\begin{array}{l}\text { Twist and hematoma (1 LmM), } \\
\text { diabetes (1 LmM) }\end{array}$ \\
\hline & Stryphnodendron adstrigens & Barbatimão & 11 & $\begin{array}{l}\text { Wound healing (10 LM), cold } \\
\text { and flu (1 LmM) }\end{array}$ \\
\hline
\end{tabular}




\begin{tabular}{|c|c|c|c|c|}
\hline Bromeliaceae & $\begin{array}{l}\text { Bromelia } \\
\text { antiacantha Bertol. }\end{array}$ & Caraguatá & 4 & Asthma and bronchitis (4 LM) \\
\hline Caesalpiniaceae & Cassia angustifolia Vahl. & Sene & 4 & Lose weight (4 LmM) \\
\hline \multirow{3}{*}{ Bignoniaceae } & Jacaranda caroba (Vell.) & Caroba & 1 & Diabetes (1 LmM) \\
\hline & Pyrostegia venusta & Cipó-de-são-joão & 1 & Diverticulitis (1 LmM) \\
\hline & Vernonia polyanthes (Less.) & Assa-peixe & 1 & Cold and flu (1 LM) \\
\hline Burseraceae & heptaphyllum & Breu & 1 & Burn (1 LM) \\
\hline Portulacaceae & Portulaca pilosa L. & Beldroega & 2 & Stomach pain (2 LmM) \\
\hline Solanaceae & $\begin{array}{l}\begin{array}{l}\text { Solanum } \\
\text { (Mill.) }\end{array} \\
\end{array}$ & Maria-preta & 2 & Wound healing (2 LM) \\
\hline
\end{tabular}

$\mathrm{NC}=$ number of citations for each species; RU = referred use (number of citations for such therapeutic use); $\mathrm{LM}=$ literature-matched; $\mathrm{LmM}=$ literature-mismatched.

In addition, in the same table it is possible to observe the number of citations for each species, for each application, and whether the use was match or not with the information described in the literature. Only 30 of the 76 use citations for the plants were found in the literature, $39.5 \%$ of the total. In this direction, the popular use of Achyrocline satureioides cited in this study for stomach pain and menstrual cramps is related to antidyspeptic and antispasmodic potential cited in the scientific literature (BARATA et al., 2009a). Already, the use of this species for headache is not described in the scientific literature. For the Anadenanthera colubrina no scientific basis was found for the use of this species in the treatment of sprain, hematoma and diabetes. Other effects have been attributed to this plant and were not described in this study (WEBER et al., 2011).

The species with the highest number of citations was Baccharis trimera. This plant was cited 38 times for nine different therapeutic effects, and only one of them was described in the scientific literature. According to the Herbal Form of the Brazilian Pharmacopoeia (BRASIL, 2011) this medicinal plant is indicated for digestive discomforts, aligned to its use for stomach pain, mentioned 10 times in the survey. Nevertheless, the hypoglycemic (OLIVEIRA et al., 2005) and diuretic effects (OLIVEIRA; AKISUE, 2010) of Baccharis trimera, well described in the literature, were not cited by the respondents.

Studies have revealed the use of the Bromelia antiacantha fruits in the form of syrup for cough treatment (MARQUES; GUTIÉRREZ; DEL RIO, 2007), asthma and bronchitis (ZANELLA, 2009), corroborating the uses cited by the respondents in the present study. The proven therapeutic uses as a laxative and purgative of Cassia angustifolia (OLIVEIRA; AKISUE, 2010) may explain why the respondents have mentioned this species as a means to lose weight, thereby contextualizing the irregular use of this plant. The reported pharmacological action is related to the presence of anthraquinones, substances commonly found in this species that exert activity on intestinal smooth muscle (SIMÕES et al., 2010).

The chemical composition of Hypericum perforatum attracts the attention of many researchers because of its wide variety of different secondary metabolites. $H$. perforatum contains at least 10 classes of biologically active compounds, including napthodianthrone, known as hypericin in this plant, responsible for the antidepressant (GREESON; SANFORD; MONTI, 2001), antiviral and antitumoral activity (MISKOVSKY, 2002; KUBIN et al., 2005). However, in the scientific literature, no studies were found to confirm the anxiolytic activities and positive effect against menstrual cramps.

We have not found any scientific reference for the use of Jacaranda caroba as a hypoglycemic agent. Ierobina ${ }^{\circledR}$, a Brazilian phytopharmaceutical product, indicated for the treatment of dyspepsia, contains in its formulation the fluid extract of Jacaranda caroba. However, this use was not cited by respondents. Medicinal effect of Portulaca pilosa to treat stomach pain is also not described in the literature. We have only found reports of some analgesic and anti-inflammatory activities for this plant, which have been attributed to a hydroethanolic extract obtained from the plant's aerial parts (BARATA et al., 2009b). The species Protium hepthaphylum has been described as possessing healing and anti-inflammatory properties (LORENZI; MATOS, 2008), justifying its use for treating burns. The presence of $\alpha$ - and $\beta$-amyrin, triterpenes of anti-inflammatory activity, probably accounts for this activity (OLIVEIRA et al., 2005).

$$
\text { Pyrostegia venusta's effect against }
$$

diverticulitis has not been reported. Antiinflammatory and healing activities were observed for a methanol extract obtained from the flowers of 
Medicinal plants...

this species (ROY et al., 2012) but these activities were not cited in our study. Mentioned uses for Solanum americanum, especially the treatment and healing of wounds, were confirmed in the literature. Its anti-inflammatory and healing actions have been described as not only treating psoriasis and eczema but also relieving itching (LORENZI; MATOS, 2008). Also reported in the literature are its antimicrobial, antiviral, cytotoxic, antifungal (FENNER et al., 2006), antiulcerogenic and antitumor (NGUELEFACK et al., 2008) activities. These reports demonstrate the importance of this genus in folk medicine, where many plant species can still be studied for the discovery of novel bioactive compounds.

The healing effect of Stryphnodendron adstrigens cited in the present study for treatment of wounds has already been described in the scientific literature (PINTO et al., 2015). Administration of this plant has also shown apoptosis-induced antitumoral activity in lymphomas and melanomas. (BALDÍVIA; LEITE; CASTRO, 2018; CARVALHO et al., 2019). However, we have not found published data to justify its use for cold and flu, cited in
SANTOS, L. et al.

the interview. In agreement with the mentioned use for treatment of cold and flu, the Vernonia polyanthes is scientifically reported for bronchitis and persistent cough, as an expectorant (BRASIL, 2011).

Uniformity among the therapeutic uses surveyed in the study population was assessed by a fidelity index, and the related parameters AMU and cAMU, for each of the mentioned Cerrado species (Table 4). Among the reported uses for the Baccharis trimera, the most cited was weight loss, totaling 15 reports. For this purpose, this plant obtained the highest AMU, i.e., the higher agreement to a main use (51.7\%) and the same value was obtained for the cAMU. This because the correction factor of the Baccharis trimera species was obtained by dividing the number of individuals, 29 , who cited the species in analysis (ISA), by the number of individuals who cited the species that presented a larger number of therapeutic uses (ISLN). In this case also 29, because for the species Baccharis trimera nine different therapeutic uses were cited. Hence, in this study, for the calculation of the correction factor of all plants, the ISLN value considered was 29 .

Table 4. Uniformity of therapeutic uses most often cited for Cerrado species.

\begin{tabular}{|c|c|c|c|c|c|c|c|}
\hline Cerrado species & Most cited uses & IMU & IAU & $\operatorname{AMU}(\%)$ & ISA & $\mathbf{C F}$ & cAMU $(\%)$ \\
\hline Achyrocline satureoides & Headache & 02 & 04 & 50.0 & 04 & 0.14 & 6.9 \\
\hline Anadenanthera Colubrina & $\begin{array}{l}\text { Torsion } \\
\text { hematoma }\end{array}$ & 01 & 02 & 50.0 & 02 & 0.07 & 3.4 \\
\hline Baccharis trimera & Weight loss & 15 & 29 & 51.7 & 29 & 1.00 & 51.7 \\
\hline Bromelia antiacantha & $\begin{array}{l}\text { Asthma } \\
\text { bronchitis }\end{array}$ & 04 & 04 & 100.0 & 04 & 0.14 & 13.8 \\
\hline Cassia angustifolia & Weight loss & 03 & 03 & 100.0 & 03 & 0.10 & 10.3 \\
\hline Hypericum perforatum & Soothing & 03 & 05 & 60.0 & 05 & 0.17 & 10.3 \\
\hline Jacaranda caroba & Diabetes & 01 & 01 & 100.0 & 01 & 0.03 & 3.4 \\
\hline Portulaca pilosa & Stomachache & 01 & 01 & 100.0 & 01 & 0.03 & 3.4 \\
\hline Protium heptaphyllum & Burns & 01 & 01 & 100.0 & 01 & 0.03 & 3.4 \\
\hline Pyrostegia venusta & Diverticulitis & 01 & 01 & 100.0 & 01 & 0.03 & 3.4 \\
\hline Solanum americanum & Headache & 01 & 01 & 100.0 & 01 & 0.03 & 3.4 \\
\hline $\begin{array}{l}\text { Stryphnodendron } \\
\text { adstrigens }\end{array}$ & $\begin{array}{l}\text { Wounds } \\
\text { healing }\end{array}$ & 09 & 09 & 100.0 & 09 & 0.31 & 31.0 \\
\hline Vernonia polyanthes & Cold and flu & 01 & 01 & 100.0 & 01 & 0.03 & 3.4 \\
\hline
\end{tabular}

IMU = number of individuals who cited the main use of species (i.e., use what was most cited); IAU = number of individuals who cited the species of the Cerrado plants for any use; AMU = percentage agreement regarding the main uses; ISA = number of individuals who cited the species in analysis; $\mathrm{CF}=$ correction factor; cAMU = percentage of agreement on the corrected main uses. 
The species Stryphnodendron adstrigens presented a cAMU of $31 \%$ and an individual AMU of $100 \%$, followed by the species Cassia angustifolia and Bromelia antiacantha, both with cAMU of only $10.3 \%$, but with the AMU of $100 \%$, since all respondents used them for the same purpose.

\section{DISCUSSION}

Respondents who participated in this study, and in particular those who reported knowledge and/or use of medicinal plants, $90.5 \%$ of the total, were mostly women, older than 60 years and with incomplete elementary school degree. Thus, by initially establishing a correspondence between the data obtained from the socioeconomic character questions, an inverse relationship was found in this study between age and level of education, i.e., older respondents had lower education levels. Thirty-one of the respondents older than 60 years, $58.06 \%$ of the total, had not completed elementary school. Regarding to this, it has been supposed that elderly people see medicinal plants as substitutes for synthetic medicines because of their fewer sideeffects, lower cost, and facilitated access (PEREIRA et al., 2016).

Contrarily, a direct correlation was found between knowledge about medicinal plants and lower levels of education. Only 26 out of the 135 respondents who reported knowledge and/or use of medicinal plants had at least started high education. Similarly, vendors of medicinal plants were also characterized as education- and income-deprived persons by a study carried out in four Brazilian cities of Rio Grande do Norte State. Among those vendors, knowledge on medicinal plants also transmits from one generation to another (ARAÚJO et al., 2017).

In Brazil, people with lower income depend on the services provided by the public health system to ensure medical service and treatment access. Besides that, taking into account the low purchasing power of most of the population in Brazil (MEDEIROS; SOUZA; CASTRO, 2015), and the precariousness of public health service (TORRES et al., 2010), it becomes evident that people search for alternative treatments because of their cost / benefit. According to the World Health Organization (WHO), much of the population in developing countries depend on traditional medicine for their primary health care; it is estimated that $80 \%$ of this population employ traditional practices in their primary health care while $85 \%$ utilize medicinal plants or preparations thereof (VEIGA JUNIOR,
2008, EKOR, 2014). In this regard, the present ethnobotanical research identified the therapeutic uses of 115 plant species, which were cited by their popular names on the questionnaires. Surprisingly, according to a floristic survey conducted in surrounding areas of the Assis Ecological Station, only 13 out of the 115 cited species pertain to the Cerrado vegetation (DURIGAN et al., 2011).

Cerrado hosts more than 12.400 plant species and one third of Brazilian biodiversity with a high level of endemism, making it the most biodiverse savanna on the planet (SANO et al., 2019). Many of these plants have scientificallyproven medicinal effects. For instance, the study by Cardozo et al. (2018) listed the soursop (Annona muricata) for treating ulcers, the macauba palm (Acrocomia aculeata) for controlling diabetes and improving diuresis, the baru seeds (Dipteryxalata alata) for improving lipid and atherogenic profiles, and the pequi (Caryocar brasiliense) which has anti-inflammatory, antioxidant, and hepatoprotective properties.

The results obtained in this study suggest that the local population is unaware of the therapeutic properties of many existing plants in the region. The lack of knowledge about Cerrado plants was evident in our study as only $31 \%$ of 135 respondents reported to know and/or the use medicinal plants from this biome. The number of use citations for Cerrado plants corresponded to only $9 \%$ of the total citations for all plants. In addition, by establishing a relation between the number of citations and the number of individuals, a value of 6.2 citations per individual was obtained for plants in general and 1.8 for plants of the Cerrado. Oliveira et al. (2019) have suggested that the dearth of knowledge on the importance of Cerrado plants poses an obstacle to the biome conservation. Also, according to Batista (2009), a narrow engagement from government to avert Cerrado degradation and the population's unawareness of the importance of its vegetation have contributed to the fast devastation of this biome, Therefore, until the value of the Cerrado species is thoroughly understood, by both government and population, conservation of this important Brazilian biome might not be achieved.

Another important aspect evidenced in this study refers to the therapeutic uses cited by the respondents for Cerrado plants. From a review of the literature, it was verified that for the few plants cited, several mentioned purposes have not been not scientifically described. More precisely, $60.5 \%$ of the total of the purposes were not found in the scientific literature. The Brazilian citizens who 
employ medicinal plants are often unaware of their therapeutic activities and their possible toxicity (FERREIRA et al., 2014).

In ethnobotanical studies, analyses AMU and cAMU to evaluate agreement on the main use of medicinal plants are employed to reveal the most widespread and accepted popular uses (SILVA, 2010). To identify the uniformity of the cited therapeutic uses and to better interpret the agreement of main use of the Cerrado species, these parameters were established. Among the referenced uses of Baccharis trimera species, the most cited use was weight loss, totaling 15 reports. For this purposeuse, this plant has obtained the higher cAMU value among all cited species, i.e., the higher agreement for a popular use $(51.7 \%)$. This could appoint to a truly effective action of this plant for wight loss, although no scientific study has validated hypothesis so far.

On the other hand, a low cAMU value for a given species does not necessarily indicate that treatment with this plant is not effective. It rather indicates that the popularity of this species is lower than it is for the other plants. Indeed, the species Stryphnodendron adstrigens, mentioned nine times, showed a low cAMU value, i.e., low agreement to a popular use, while a value of $100 \%$ for AMU was also found. This is because all respondents who cited this plant use it for the same purpose, the treatment of wound healing, in this case. Such medicinal use has been described in the scientific literature (PINTO et al., 2015).

The analysis of the variables AMU and cAMU, although suitable to indicate the coherence of a medicinal use for a given plant among people, is only suggestive an actual pharmacological effect. Observations must still be confirmed by pre-clinical and clinical studies for safety and efficacy assessment. So, ethnobotanical studies provide useful information for ethnopharmacological research, from the knowledge often enshrined in popular use to scientifically based investigations. According to Amorozo (1996) and Tugume et al. (2016) the combination of ethnobotanical and ethnopharmacological study enables the preservation of cultural information transmitted across generations, provides an appreciation of herbal medicine, and the maintenance of plant species.

The fact that several Brazilian Cerrado plant species were not cited in this study indicates the highly limited knowledge of the local population about Cerrado plants. In addition, even for the few Cerrado species that were cited in this study, many of the therapeutic effects described in the literature were unknown by respondents. Also, some of the uses cited by them are still not validated by scientific research. Thus, the results show a scarce and weak connection between popular and scientific knowledge on the medicinal plants of the Cerrado, what could contribute to the devastation of this biome.

The Brazilian document entitled National Policy for Medicinal Plants, of 2006, pointed out the promotion of population's life quality and forests conservation by sustainable, safety and rational usage of medicinal plants (BRASIL, 2006). Nascimento et al. (2017) have suggested that the interaction between universities and the population in informative meetings and debates highlighting the importance of sustainable and correct usage medicinal plants might be positive for environmental conservation. Therefore, following our findings in this study, we have disseminated information about Cerrado's medicinal plants and the benefit of their correct and sustainable use for the biome preservation via social networks, local newspapers, lectures, short courses, and scientific events.

The development of ethnobotanical researches could rescue the local knowledge of the population about medicinal plants of the Cerrado. Ethnopharmacological studies could also elucidate the chemical composition of medicinal plants of the Brazilian Cerrado, determine their pharmacological and toxicological actions, and ensure their correct therapeutic and sustainable use. Hence, this kind of research would serve as an important tool to foster the appreciation and conservation of this biome, contributing to improvement of population's quality of life.

Additionally, ethnobotanical and ethnopharmacological studies should be accompanied by the propagation of knowledge to the population and private and public organizations, aiming to facilitate the economic exploitation of these plants by the industry, in general. If not, this lack of knowledge of the properties of the Cerrado plants and its biological wealth would end up to the total devastation of this important biome.

In conclusion, ethnobotanical and ethnopharmacological studies have been shown as an essential strategy for obtaining scientific recognition of the chemical and pharmacological properties of the Cerrado plants and is the main, if not the only means of promoting the appreciation and preservation of this biome, and the social and economic development of the people who live in it. 


\section{ETHICAL APPROVAL}

All procedures performed in studies involving human participants were in accordance with the ethical standards of the institutional and/or national research committee and with the 1964 Helsinki declaration and its later amendments or comparable ethical standards.

\section{ACKNOWLEDGEMENTS}

The authors are grateful to Secretaria Municipal da Saúde de Assis - SP. We are also thankful to Daniel S. Moura and Victor A. P. Rodrigues for the technical revision and improvements made over the manuscript text.

RESUMO: O Cerrado é o segundo maior bioma do Brasil, apresenta uma diversidade ecológica imensurável e ainda pouco explorada. Apesar da exuberância de suas espécies endêmicas, é um dos 25 hotspots globais, pois apresenta alta riqueza natural em termos de biodiversidade e destruição expressiva de seu meio ambiente. Neste estudo, pesquisamos o conhecimento sobre o uso medicinal de plantas do Cerrado entre indivíduos que vivem em uma região predominantemente do Cerrado. Um questionário individual semiestruturado com perguntas de caráter socioeconômicas qualitativas e referentes ao uso medicinal de plantas foi aplicado aos usuários do Serviço de Saúde Pública da cidade de Assis, Estado de São Paulo, Brasil. Este estudo foi aprovado pelo Comitê de Ética do Hospital Regional de Assis (Protocolo 4812010). Dos 149 entrevistados, 90,6\% relataram conhecimento e / ou uso de plantas para fins terapêuticos. Entre as 115 espécies de plantas mencionadas, $11,4 \%$ pertencem ao Cerrado. Também avaliamos a correlação entre os usos relatados e os respectivos dados publicados em estudos científicos sobre as propriedades medicinais das plantas. Verificou-se que, para as poucas plantas de Cerrado citadas, os entrevistados descreveram diversas aplicações medicinais não descritas cientificamente. Mais precisamente, $60,5 \%$ do total das aplicações medicinais não foram encontrados na literatura científica. Além disso, muitos dos efeitos terapêuticos descritos na literatura para as espécies do Cerrado não foram citados pela população entrevistada. Portanto, sugerimos que o fortalecimento da conexão entre conhecimento popular e científico, aliado à disseminação desse conhecimento, poderia contribuir para uma maior valorização do bioma Cerrado e consequentemente a preservação do mesmo.

PALAVRAS-CHAVE: Conhecimento popular. Conhecimento científico. Valorização do bioma.

\section{REFERENCES}

AMOROZO, M. C. M.; GÉLY, A. Uso de plantas medicinais por caboclos do baixo amazonas, Barcarena, PA, Brasil. Boletim do Museu Paraense Emílio Goeldi, Série Botânica, Belém, v. 4, n. 1, p. 47-131, 1988.

AMOROZO, M. C. M. A abordagem etnobotânica na pesquisa de plantas medicinais. In: DI STASI, L. C. (Org.). Plantas medicinais: arte e ciência - Um guia de estudo interdisciplinar. São Paulo: EDUSP, 1996. P. 4768 .

BATISTA, J. G. F. P. A importância dos biomas mundiais: e o Cerrado no contexto brasileiro. In: ENPEG - $10^{\circ}$ Encontro Nacional de Práticas de Ensino em Geografia. Porto Alegre, 2009.

BALDIVIA, D.; LEITE, D.; CASTRO, D. Evaluation of in vitro antioxidant and anticancer properties of the aqueous extract from the stem bark of Stryphnodendron adstringens. International Journal of Molecular Sciences, vol. 19, no. 8, p. 2432, 2018. https://doi.org/10.3390/ijms 19082432

BARATA, L. E. S.; ALENCAR, A. A. J.; TASCONE, M.; TAMASHIRO, J. Brazilian medicinal plants. I. Achyrocline satureioides (Lam.) DC. (Macela). Revista Fitos, v. 4, n. 1, p. 120-125, 2009a.

BARATA, L. E. S.; ALENCAR, A. A. J.; TASCONE, M.; TAMASHIRO, J. Brazilian medicinal plants. II. Portulaca pilosa L (Amor-crescido). Revista Fitos, v. 4, n. 1, p. 120-125, 2009 b.

BARBOSA, F.M. CERRADANIA: Alumeia e óia pros encantamentos dos cerratenses. 1. ed. Brasília: Clube de Autores, 2017. 190 p. 
Medicinal plants...

SANTOS, L. et al.

BRASIL. Ministério da Saúde. Secretaria de Ciência, Tecnologia e Insumos Estratégicos, Departamento de Assistência Farmacêutica. Política Nacional de Plantas Medicinais e Fitoterápicos. Brasília: Ministério da Saúde, 2006.

BRASIL. Agência Nacional de Vigilância Sanitária. Formulário de Fitoterápicos da Farmacopéia Brasileira. Agência Nacional de Vigilância Sanitária, Anvisa. Brasília, Brasil, 2011.

CARDOZO, C. M. L.; INADA, A. C.; MARCELINO, G.; FIGUEIREDO, P. S.; ARAKAKI, D. G.; HIANE, P. A.; CARDOSO, C. A. L.; GUIMARÃES, R. C. A.; FREITAS, K. C. Therapeutic potential of Brazilian Cerrado Campomanesia species on metabolic dysfunctions. Molecules, v.23, 17 p. 2018. https://doi.org/10.3390/molecules23092336

CARVAlHO, J. T. G.; BAldiviA, D. S.; LEITE, D. F.; ARAÚJO, L. C. A.; ESPINDOLA, P. P. T.; ANTUNES, K. A.; ROCHA, P. S.; SOUZA, K. P.; SANTOS, E. L. Medicinal plants from Brazilian Cerrado: antioxidante and anticancer potential and protection against chemotherapy toxicity. Oxidative medicine and cellular longevity. 16p. 2019. https://doi.org/10.1155/2019/3685264

DURIGAN, G.; MELO, A. C. G.; MAX, J. C. M.; VIlAS BOAS, O.; CONTIERI, W. A.; RAMOS, V. S. Manual para recuperação da vegetação de Cerrado. 3. ed. São Paulo: SMA, 2011. 26 p.

DUTRA, R. C., CAMPOS, M. M., SANTOS, A. R. S.; CALIXTO, J. B. Medicinal plants in Brazil: Pharmacological studies, drug discovery, challenges and perspectives. Pharmacological Research, 112, 4-29, 2016. https://doi.org/10.1016/j.phrs.2016.01.021

EKOR, M. The Growing Use of Herbal Medicines: Issues Relating to Adverse Reactions and Challenges in Monitoring Safety. Frontiers in Pharmacology, Suíça, v. 4, p. 1-10, 2014. https://doi.org/10.3389/fphar.2013.00177

FENNER, R.; BETTI, A. H.; MENTZ, L. A.; RATES, S. M. K. Plantas utilizadas na medicina popular brasileira com potencial atividade antifúngica. Revista Brasileira de Ciências Farmacêuticas, São Paulo, v. 42, n. 3, p. 369-394, 2006. https://doi.org/10.1590/S1516-93322006000300007

FERREIRA, T. S.; MOREIRA, C. Z.; CÁRIA, N. Z.; VICTORIANO, G.; SILVA JR, W. F.; MAGALHÃES, J. C. Phytotherapy: na introduction to its history, use and application. Revista Brasileira de Plantas Medicinais, v.16, n.2, p. 290-298, 2014. https://doi.org/10.1590/S1516-05722014000200019

FRIEDMAN, J.; YANIV, Z.; DAFNI, A.; PALEWITCH, D. A preliminary classification of the healing potential of medicinal plants, based on a rational analysis of an ethnopharmacological field survey among Bedouins in the Negev Desert, Israel. Journal of Ethnopharmacology, South Africa, v. 16, n. 2-3, p. $275-287,1986$. https://doi.org/10.1016/0378-8741(86)90094-2

FÜRSTENBERG-HÄGG J., ZAGROBELNY M., BAK, S. Plant defense against insect herbivores. International Journal of Molecular Sciences, v.14, p.10242-10297, 2013. https://doi.org/10.3390/ijms140510242

GREESON, J. M.; SANFORD, B.; MONTI, D. A. St. John's wort (Hypericum perforatum): a review of the current pharmacological, toxicological, and clinical literature. Journal of Psychopharmacology, South Africa, v. 153, n. 4, p. 402-414, 2001. https://doi.org/10.1007/s002130000625

KLINK, C. A.; MACHADO, R. B. A conservação do cerrado brasileiro. Megadiversidade, São Paulo, v. 1, n. 1, p. $147-155,2005$.

KUBIN, A.; WIERRANI. F.; BURNER, U.; ALTH, G.; GRÜNBERGER, W. Hypericin - the facts about a controversial agent. Current Pharmaceutical Design, Estados Unidos, v. 11, n. 2, p. 233-253, 2005. https://doi.org/10.2174/1381612053382287 
Medicinal plants...

SANTOS, L. et al.

LORENZI, H.; MATOS, F. J. A. Plantas medicinais no Brasil - Nativas e Exóticas. 2. ed. São Paulo: Nova Odessa, 2008. 576 p.

MARQUES, G.; GUTIÉRREZ, A.; DEL RIO, J. C. Chemical characterization of lignin and lipophilic fractions from leaf fibers of curaua. Journal of Agricultural and Food Chemistry, Estados Unidos, v. 55, n. 4, p. 13271336, 2007. https://doi.org/10.1021/jf062677x

MEDEIROS, M.; SOUZA, P. H. G. F.; CASTRO, F. A. The stability of income inequality in Brazil, 2006-2012: an estimate using income tax data and household surveys. Ciência \& Saúde Coletiva, Rio de Janeiro, v. 20, n. 4, p. 971-986, 2015. https://doi.org/10.1590/1413-81232015204.00362014

MISKOVSKY, P. Hypericin a new antiviral and antitumor photosensitizer: mechanism of action and interaction with biological macromolecules. Current Drug Targets, Estados Unidos, v. 3, p, 55-84, 2002. https://doi.org/10.2174/1389450023348091

MITTERMEIER, R. A.; FONSECA, G. A. B.; RYLANDS, A. B.; BRANDON, K. A brief history of biodiversity conservation in Brazil. Conservation Biology, Reino Unido, v. 19, p. 601-611, 2005. https://doi.org/10.1111/j.1523-1739.2005.00709.x

NGUELEFACK, T. B.; FEUMEBO, C. B.; ATEUFACK, G.; WATCHO, P.; TATSIMO, S.; ATSAMO, A. D.; TANE, P.; KAMANUI, A. Anti-ulcerogenic properties of the aqueous and methanol extracts from the leaves of Solanum torvum Swartz (Solanaceae) in rats. Journal of Ethnopharmacology, South Africa, v. 119, p. 135140, 2008. https://doi.org/10.1016/j.jep.2008.06.008

OLIVEIRA, F. A.; CHAVES, M. H.; ALMEIDA, F. R. C.; LIMA JR, R. C. P.; SILVA, R. M.; MAIA, J. L.; BRITO, G. A. A. C.; SANTOS, F. A.; RAO, V. S. Protective effect of $\alpha$ - and $\beta$-amyrin, a triterpene mixture from Protium heptaphyllum (Aubl.) March. trunk wood resin, against acetaminophen-induced liver injury in mice. Journal of Ethnopharmacology, South Africa, v. 98, p. 103-108, 2005. https://doi.org/10.1016/j.jep.2005.01.036

OLIVEIRA, F; AKISUE, G. Fundamentos de Farmacobotânica e de Morfologia Vegetal. 1. ed. São Paulo: Atheneu, 2010. 224 p.

OLIVEIRA, H. W. C.; VIVEIRO, A. A. Cerrado e plantas medicinais: algumas reflexões sobre o uso e a conservação. Ensino, Saúde e Ambiente, Rio de Janeiro, v. 5, n. 3, p. 102-120, 2012. https://doi.org/10.22409/resa2012.v5i3.a21016

OLIVEIRA, S.R.; LIMA-RIBEIRO, M.S.; SOUZA, A.O.; SANTOS, C.E.; SILVA, K.V.; ZÓRTEA, M.; GUILHERME, F.A.G.; MELO, F.R.; CARNEIRO, S.E.S.; SILVA, W.V.; MORAIS, A.R. Are protected áreas effective in preserving anurans and promoting biodiversity discoveries in the Brazilian Cerrado? Journal for Nature Conservation, v.52, 5p, 2019. https://doi.org/10.1016/j.jnc.2019.125734

PINTO, S. C.; BUENO, F. G.; PANIZZON, G. P.; MORAIS, G.; DOS SANTOS, P. V.; BAESSO, M. L.; LEITE-MELLO, E. V.; DE MELLO, J. C. Stryphnodendron adstringens: Clarifying Wound Healing in Streptozotocin-Induced Diabetic Rats. Planta Medica, Alemanha, v. 81, n.12-13, p. 1090-1096, 2015. https://doi.org/10.1055/s-0035-1546209

RIBEIRO-JÚNIOR, J. W.; BERTOLUCI, J. Anuros do Cerrado da Estação Ecológica e da Floresta Estadual de Assis, sudeste do Brasil. Biota Neotropica, São Paulo, v. 9, p. 207-216, 2009. https://doi.org/10.1590/S167606032009000100020

RIBEIRO, D.A.; OLIVEIRA, L.G.; MACÊDO, D.G.; MENEZES, I.R.; COSTA, J.G.; SILVA, M.A.; LACERDA, S.R.; SOUZA, M.M. Promising medicinal plants for bioprospection in a Cerrado area of Chapada do Araripe, Northeastern Brazil. Journal of Ethnopharmacology, v.155, n.3, p. 1522-1533, 2014. https://doi.org/10.1016/j.jep.2014.07.042 
ROSSATO, D. R.; TONIATO, M. T. Z.; DURIGAN, G. Flora fanerogâmica não-arbórea do Cerrado na Estação Ecológica de Assis, Estado de São Paulo. Revista Brasileira de Botânica, São Paulo, v. 31, p. 409-424, 2008. https://doi.org/10.1590/S0100-84042008000300005

ROY, P.; AMDEKAR, S.; KUMAR, A.; SINGH, R.; SHARMA, P.; SINGH, V. In vivo antioxidative property, antimicrobial and wound healing activity of flower extracts of Pyrostegia venusta (Ker Gawl) Miers. Journal of Ethnopharmacology, South Africa, v. 140, p. 186-192, 2012. https://doi.org/10.1016/j.jep.2012.01.008

SANCHÉZ-SANCHÉZ, H.; MORQUECHO-CONTRERAS, A. Chemical Plant Defense against Herbivores, InTech, 2017. https://doi.org/10.5772/67346

NASCIMENTO, R. V. do; VIEIRA, D. S.; SIMONARD, P.; REGIS, R. C. L. A.; ALVIM, R. G. Plantas medicinais como proposta de intervenção na educação ambiental à luz da legislação vigente. Educação ambiental em ação, v. 61, p. 1, 2017.

SANO, E. E.; RODRIGUES, A. A.; MARTINS, E. S.; BETTIOL, G. M.; BUSTAMANTE, M. M. C.; BEZERRA, A. S.; COUTO JR, A. F.; VASCONCELOS, V.; SCHÜLER, J.; BOLFE, E. L. Cerrado ecoregions: a spatial framework to assess and prioritize Brazilian savana environmental diversity for conservation. Journal of Environmental Management, v. 232, p.818-828, 2019. https://doi.org/10.1016/j.jenvman.2018.11.108

SANTOS, R. L.; GUIMARÃES, G. P.; NOBRE, M. S. C.; PORTELA, A. S. Análise sobre a fitoterapia como prática integrativa no Sistema Único de Saúde. Revista Brasileira de Plantas Medicinais, Botucatu, v. 13, n. 4, p. 486-491, 2011. https://doi.org/10.1590/S1516-05722011000400014

SANTOS, L. P.; ARAUJO, D. R. Aspectos socioeconômicos dos municípios Brasileiros com ocorrência de tráfico de animais silvestres no Bioma Cerrado. Élisée - Revista de Geografia da UEG, Goiás, v. 4, n. 2, p. 211- 220, 2015.

SILVA, M. P. Etnobotânica de Comunidades Rurais da Serra de Campo Maior - Piauí, Brasil, In: Lopes WGR et al., (Orgs.). Cerrado piauiense: uma visão multidisciplinar, EDUFPI: Série Desenvolvimento e Meio Ambiente, Teresina, Piauí, 2010.

SIMÕES, C. M. O.; SCHENKEL, E. P.; GOSMANN, G.; MELLO, J. C. P.; MENTZ, L. A.; PETRVICK, P. R. Farmacognosia: da Planta ao Medicamento. 6. ed. Porto Alegre: Editora da UFRGS, Florianópolis, 2010. 1104 p.

TAIZ, L.; ZEIGER, E. Plant physiology. 3. ed. Sounderland: Sinauer Associates, 2010. 690 p.

TORRES, C. A.; BARBOSA, S. M.; PINHEIRO, P. N. C.; VIEIRA, N. F. C. Health and popular education with adolescents. Revista da Rede de Enfermagem do Nordeste, Ceará, v. 11, p. 47-56, 2010.

TUGUME, P.; KAKUDIDI, E.K.; BUYINZA, M.; NAMAALWA, J.; KAMATENESI, M.; MUCUNGUZI, P.; KALEMA, J. Ethnobotanical survey of medicinal plant species used by communities around Mabira Central Forest Reserve, Uganda. Journal of Ethnobiology and Ethnomedicine, v.12, n.5, 28p., 2016. https://doi.org/10.1186/s13002-015-0077-4

VEIGA JUNIOR, V. F. Estudo do consumo de plantas medicinais na Região Centro-Norte do Estado do Rio de Janeiro: aceitação pelos profissionais de saúde e modo de uso pela população. Revista Brasileira de Farmacognosia, Curitiba, v. 18, n. 2, p. 308-313, 2008. https://doi.org/10.1590/S0102-695X2008000200027

WEBER, C. R.; SOARES, C. M. L.; LOPES, A. B. D.; SILVA, T. S.; NASCIMENTO, M. S.; XIMENES, E. C. P. A. Anadenanthera colubrina: a therapeutic potential study. Revista Brasileira de Farmacologia, v.92, n.4, p. 235-244, 2011. 
Medicinal plants...

SANTOS, L. et al.

ZANELLA, C. Caracterização genética, morfológica e fitoquímica de populações de Bromelia antiacantha (Bertol.) do Rio Grande do Sul. 2009. 98 f. Dissertação (Mestrado em Genética e Biologia Molecular). Universidade Federal do Rio Grande do Sul, Porto Alegre. 